University of Nebraska - Lincoln

DigitalCommons@University of Nebraska - Lincoln

$10-1913$

\title{
THE SOUTHWESTERN COWBOY SONGS AND THE ENGLISH AND SCOTTISH POPULAR BALLADS
}

Louise Pound

Follow this and additional works at: https://digitalcommons.unl.edu/englishfacpubs

Part of the Comparative Literature Commons, English Language and Literature Commons, Modern Literature Commons, and the Reading and Language Commons

This Article is brought to you for free and open access by the English, Department of at DigitalCommons@University of Nebraska - Lincoln. It has been accepted for inclusion in Faculty Publications -Department of English by an authorized administrator of DigitalCommons@University of Nebraska - Lincoln. 


\section{THE SOUTHWESTERN COWBOY SONGS AND THE ENGLISH AND SCOTTISH POPULAR BALLADS}

Several writers recently have found analogy between the conditions attending the growth of cowboy songs in isolated communities in the Southwest, and the conditions under which arose the English and Scottish popular ballads-those problematic pieces which form so special a chapter in the history of English poetry. Mr. Lomax, the chief collector of southwestern folk songs, ${ }^{1}$ notes, when speaking of western communities, how "illiterate people and people cut off from newspapers and books, isolated and lonelythrown back on primal resources for entertainment and for the expression of emotion-utter themselves through somewhat the same character of songs as did their forefathers of perhaps a thousand years ago." Professor Barrett Wendell ${ }^{2}$ suggests that it is possible to trace in this group of American ballads "the precise manner in which songs and cycles of songs-obviously analogous to those surviving from older and antique times-have come into being. The facts which are still available concerning the ballads of our own Southwest are such as should go far to prove, or to disprove, many of the theories advanced concerning the laws of literature as evinced in the ballads of the Old World." Ex-President Roosevelt affirms in a personal letter to Mr. Lomax ${ }^{3}$ that "there is something very curious in the reproduction here on this new continent of essentially the conditions of ballad-growth which obtained in mediaeval England."

The parallel felt by these writers is worked out, with more specific detail and greater definiteness, by Professor W. W. Lawrence, in a passage prefixed to a discussion of the ballads of Robin Hood:4

These men, living together on the solitary ranches of Texas, Arizona, or New Mexico, have been accustomed to entertain each other after the

1 Cowboy Songs. Collected by John A. Lomax. New York, 1910. See also G. W. Will, "Songs of Western Cowboys," Journal of A merican Folk-Lore,, XXII, XXVI.

2 Lomax, Cowboy Songs, Introduction.

s Ibid., Preflxed letter, dated from Cheyenne, 1910.

4 Medieval Story. New York, 1911.

[Modern Philology, October, 1913 
day's work is done by singing songs, some of which have been familiar to them from boyhood, others of which they have actually composed themselves. . . . . These cowboy ballads are not the expression of individuals but of the whole company which listens to them, and they are, in a very real sense, the work of other men than the author. . . . . The author counts for nothing, it will be observed; his name is generally not remembered, and what he invents is as characteristic of his comrades as of himself. . . . . Here we have literature which is a perfect index of the social ideals of the body of men among whom it is composed, literature which makes no pretense to literary form or to the disclosure of the emotions of any one man as distinguished from his fellows. There are few communities of the present day which are as closely united in common aims and sympathies as these bands of Western cowboys, hence there are few opportunities for the production of verse which is as truly the expression of universal emotion as are these songs.

Such Western ranches reproduce almost perfectly the conditions under which the English popular ballads were composed. . . . .

It is obvious from these passages that their writers find a real parallel between the conditions leading to the growth in our own time, in certain homogeneous communities of the Southwest, of fugitive folk pieces like those gathered by Mr. Lomax, and the conditions responsible for the rise in the Middle Ages of the traditional ballads of England and Scotland. For the student of both folk-lore and literature, the parallel so clearly set forth in the paragraphs last quoted has strong interest; and its possibilities of instructiveness are warrant for making it the basis for a brief special examination. Wherein does it hold? How far is it to be pushed? What, if anything, is indicated concerning the old World pieces by their New World analogues? Of the two leading schools of thought concerning the genesis of the English and Scottish ballads, that which may be designated the "Harvard school" emphasizes the idea of real communal composition, as by a collective village community, and adheres to a definition by origins for genuine popular ballads; that which may be called the English school ${ }^{1}$ defines by destination and style. For the mass of traditional English and Scottish folk-ballads it finds necessary the hypothesis of a higher

1 See chiefly W. J. Courthope, History of English Poetry, I (1895); G. G. Smith, The Transition Period, vi (1900); W. P. Ker, On the History of the Ballads, 1100-1500 (1910); and T. F. Henderson, Scottish Vernacular Literature (1898); Introduction to Scott's Minstrelsy of the Scottish Border (1902); and The Ballad in Literature (1912). 
origin than spontaneous popular collaboration. Which, if either, of these schools may find support in the parallel under discussion; if it be true, as Professor Wendell suggests, that the facts concerning western songs may "go far to prove, or to disprove, many of the theories advanced concerning the laws of literature as evinced in the ballads of the Old World", in which direction, if either, is the student of English balladry led?

Let us first examine, for the sake of the generalizations to be made, the subject-matter of the American pieces, and their style.

A certain percentage of the songs in the collection of Mr. Lomax are perhaps genuine cowboy pieces, approached from almost any point of view. Those which are most typical are related very closely to the life of the communities which originated and preserved them. Some of these, the editor tells us, the singers themselves composed. There are songs dealing with the life of the ranch, of the trail, songs of stampedes, of the barroom; but chiefly they deal with cattle and the cowboys who have them in charge. There are a few passing references to their "bosses"; but songs relating to these, or to the ranch-owners, songs of the lives of their employers and their families, do not appear. A few preserve the style of the ultra-sentimental or "flowery" period of American verse, ${ }^{1}$ with doubtfully westernized setting, a few are ascribed to personal authors, ${ }^{2}$ and some are plainly built on or out of well-known songs; ${ }^{3}$ but these are not wholly typical. Of what may be termed the real cowboy pieces, the following verses, cited as representative by Professor Lawrence also, will give a good idea:

I'm a rowdy cowboy just off the stormy plains,

My trade is girting saddles and pulling bridle reins,

Oh, I can tip the lasso, it is with graceful ease;

I rope a streak of lightning, and ride it where I please.

My bosses they all like me, they say I am hard to beat;

1 "By Markentura's Flowery Marge," p. 224; or the story of Amanda and Young Albon, p. 271. p. 72.

2 "Night-Herding Song," p. 324; or "The Metis Song of the Buffalo Hunters,"

"“The Cowboy's Dream" (based on "My Bonnie Lies over the Ocean"), p. 18; or "The Railroad Corral" (see Sir Walter Scott's "Bonny Dundee"), p. 318. "The Little Old Sod Shanty on the Claim," p. 187, widely known in the Mid-West, is an adaptation, it seems to the present writer, of the once very popular " The Little Old Log Cabin in the Lane." 
I give them the bold stand off, you bet I have got the cheek.

I always work for wages, my pay I get in gold;

I am bound to follow the longhorn steer until I am too old.

Ci yi yip yip yip pe ya.

Or-

Come all you jolly cowboys that follow the bronco steer,

I'll sing to you a verse or two your spirits for to cheer;

It's all about a trip, a trip that I did undergo

On that crooked trail to Holbrook, in Arizona oh.

Or-

Bill driv the stage from Independence

Up to the Smokey Hill;

And everybody knowed him thar

As Independence Bill,-

Thar warn't no feller on the route

That driv with half the skill.

As might be foreseen, though picturesque and often forceful, these pieces are crude and nearly formless, without literary quality or individual touch. ${ }^{1}$ Also they tend to be songs rather than ballads; they are more likely to express collective or individual feeling than to be verse narratives. There is an established manner, but it is crude; real poetical quality they can hardly be said to have. The Stoff is relatively unambitious and was found by the composers close at hand. No doubt it is compositions of this nature to which may fairly be ascribed the communal origin suggested by Mr. Lomax and sketched out by Professor Lawrence. These might well have found their origin in the improvisation of a community isolated and homogeneous; and they well reflect the life, the tastes, the themes, and song modes, of those among whom they are current. To reiterate, they deal as a mass with the life and the interests of the same class of people that originate them and sing them. And among this class, it is tempting to add, the pieces so composed are likely to die!

Suppose that we endeavor to distinguish, among the songs collected by Mr. Lomax, those which have found widest diffusion

${ }^{1}$ It is more than likely that even these compositions are built from well-known songs, like those cited in the preceding footnote, i.e., are adaptations. Most of them follow the model of stall ballads, or "Come all ye's," as they are sometimes designated. Of course it would be only the framework, the suggestion that is so given; the rest would be the work of some adapter, or, it may be, series of adapters. 
and greatest promise of permanence. They are not those which may fairly be thought to have originated on southwestern ranches, but rather those which may fairly be thought not to have originated there. Currency and diffusion, a sort of permanence, have been gained by a number of the better pieces; but they are pieces not peculiar to the cowboys or to the Southwest; they deal rather with outside life and topics. The very first, "O bury me not on the lone prairie," or "The Dying Cowboy," despite its title, is no communal cowboy improvisation. It has been recovered from oral tradition in Missouri, Kentucky, New England, Nebraska, and elsewhere. It is built, as is well known, on a sea piece, accessible in print," "O bury me not in the deep, deep sea." The songs "Jesse James," "The Death of Garfield," "The Days of Forty-Nine," "The Texas Rangers," "The Boston Burglar," and others have been recovered in many states of the Mid-West, East, and South. ${ }^{2}$ So with "Young Charlotte," thought by Mr. Phillips Barry to have been composed by a rural poet in Vermont, about two generations ago. " "The Dreary Black Hills," has been recovered in Missouri, Nebraska, Wyoming, and elsewhere. A version of "Mississippi Girls," localized to suit quite different conditions, ${ }^{4}$ is in the possession of the writer. For songs of the cowboy type quoted from earlier in this paper, a spontaneous origin on the trail may be a probable explanation, but not for those of the type enumerated in the preceding sentences. The latter are more likely to have drifted to than from the Southwest. ${ }^{5}$ But be that as it may, it seems to be true that the group which has achieved currency and permanence did not

1 A text appears in Fulton and Trueblood's Choice Readings, Boston, 1883; but the ascription of authorship there is probably not to be trusted.

2 Additional instances are "Fuller and Warren," “Jerry, Go Ile That Car," “The Cowboy's Lament," “Macaffle's Confession," “The Little Old Sod Shanty," “The Wars of Germany," "Fannie Moore," "Betsy from Pike," " Rosin the Bow."

3 "Native Balladry in America," Journal of American Folk-Lore, XXII, 365-73.

"The Old World ballad "The Two Brothers" (Child, 49), in a version in the possession of the writer-otherwise pretty faithful as regards narrative-seems from the surprising "way out in Idaho" of its last line to be well on its way toward becoming a western piece. A version of "Lord Randal" (Child, 12) recovered from railway camps in Colorado, under the name "Johnny Randall," has already become such. See Modern Language Notes, January, 1902.

5 The cowboys wandered into the Southwest from diverse regions and varying cultural conditions; they must have brought with them differing conceptions and models of verse, sung to diverse tunes. Mainly, however, their models would be of the stall or street ballad type. 
concern itself with the local and the special in cowboy life, but with the general, i.e., with widely known and interesting events and persons. Some, like the ballads of Jesse James and Cole Younger, or of the death of Garfield, have or had a sort of nation-wide interest. Others have some striking interest of situation or climax, or have more sustained and "artistic" execution, as "Young Charlotte"; or they were perhaps floated into diffusion by special tunefulness.

Surely songs, or ballads proper, or both, are frequently improvised even now in remote or isolated homogeneous communities, as they were in greater degree in the past; but it does not seem that these are the pieces most likely to persist and to find permanent transmission. Behind these spontaneous and inevitably crude compositions there is too little élan; not enough quality, poetic style, "art," tunefulness perhaps, not enough universality of appeal. ${ }^{1}$ It takes pressure, strong impetus, to "float" a piece into real transmission and diffusion. Even among the Texas cowboys, it is not their communal or improvised "dogie" songs which are likely to persist nearly intact among them for many decades. These rise and die, impermanent and fluctuating by nature. The better chance for life will be had by pieces like "Jesse James," or "Young Charlotte," too regular of rhyme and meter and too symmetrical of structure, though communal by preservation or destination, to be of communal origin. More likely yet, compositions of the character of "After the Ball," "There'll Be a Hot Time," "Juanita," or "Lorena," now belonging to folk-song though not originating as such, will linger among the cowboys long after their local improvisations have perished. The purpose in this paper is not to risk prediction, however, but merely to examine and contrast; and to this it is time to return.

What now of the general nature of the subject-matter and style, as related to the folk and their interests, of the English and Scottish traditional ballads? We have seen that the songs originated by the cowboys deal with the life nearest them and are couched in the rude and nearly formless style most to be expected. They deal

1 Some songs of spontaneous local composition on Wyoming ranches are in the possession of the writer, and some of similar composition brought by emigrants from mining communities at Newcastle, England. All are crude in form, and show the same commonplaceness and lack of poetical quality as the cowboy pieces. 
with the lives and the interests of the people among whom they arose and by whom they were preserved. In the many discussions regarding the authorship of the Old World ballads, the relation of the themes of the songs to the singers has had curiously little emphasis. ${ }^{1}$ Yet the subject-matter of the English and Scottish popular ballads, viewed as evidence concerning the nature of their origin, deserves from critics not incidental treatment as a side issue, but to be faced clearly as a main one.

Undoubtedly the shepherds, or knitters, or weavers, the "humble people" of mediaeval communal conditions, paralleled by those on western ranches, originated pieces of their own; as, according to the testimony of Mr. Lomax, the western cowboys occasionally do. A liking for or the gift of song may surely not be denied them. Of what would these songs treat? Would they not be most likely to deal with matters belonging to daily life; to reflect the tastes, civilization, characters, paralleled, say, by "Bill" or the "dogie" songs of the cowboy pieces? Would they not be genuinely, as regards both material and style, the "homely traditional songs of simple people," i.e., be the mediaeval counterparts of the crude pieces for which modern communal origin may be affirmed? Perhaps, too, they would more probably be songs than ballads, be lyric rather than narrative; though on this nothing special hinges.

1 The matter is dismissed (in a note) in Professor Gummere's Old English Ballads (Introd., p. xxvii) with the sentence: "This homogeneous character of a ballad-making folk, by the way, is quite enough to explain the high rank of most personages in the ballads-princes, knights, and so on." But difference between the life and interests of the hall and of the village or rural throng was very marked in the Middle Ages. This class cleavage is reflected in Froissart. Chaucer realized it when he placed knightly matter in the mouths of his aristocratic pilgrims and bourgeois matter in the mouths of those of lower class. In The Popular Ballad, Professor Gummere, while treating many matters minutely, contributes on this topic only (p. 309): “The favorite characters of the old ballad of communal tradition are the knight and the lady, wife or maid, who were in the focus of communal view and represented the fairly homogeneous life of that day." As if, for example, the "poor folk in cots" of Piers Plowman, or other humble people, were responsible for the references in balladry to bowers and falcons and knightly life, while artisans, peasants, husbandman, common soldiers, they mention not at all ? Only in The Beginnings of Poetry, a book not primarily treating the English and Scottish popular ballads, is Professor Gummere (pp. $178 \mathrm{ff}$.) much concerned with the characters and the material of these ballads. Here there is insistence again on homogeneous conditions, the "ballad community." He is content, by specific statement, with purely communal origin for the aristocratic " Edward," "The Two Brothers," and "Babylon."

How far is the hypothesis of the homogeneous character of the mediaeval community historically tenable? Cowboy society is much more homogeneous, tested by its poetry and by the general character of the life reflected, than was the mediaeval society which fostered the English and Scottish popular ballads. 
Yet folk-life and folk-themes are the one subject with which the English and Scottish traditional ballads do not deal. In direct contrast with our western pieces, the kind of people who are supposed to have preserved them are the very people who do not appear in them; much as though the cowboys sang never of themselves but only of their employers, or of those above them in the social scale. The subject-matter of the Old World pieces is aristocratic, whether they be romantic-domestic, military, or riddling; this is true, largely, even for the "greenwood" pieces. The English and Scottish ballads are well-wrought poetical tales, not crude songs, and they treat not of humble folk at all, but of kings, princesses, knights, harpers, of Lord Randal, King Estmere, Sir Patrick Spens, Young Hunting, Child Waters, Young Beichan, the Douglas and the Percy. This is true not only of a few special ballads but of the overwhelming mass, by numerical calculation. The half-dozen or so in which appear a mason, a ship-carpenter, a smith, a butler, are exceptional. The ballads are as aristocratic in their material as the metrical romances, or as mediaeval literature in general. They have a distinctive style, too, and real poetical quality, blurred by the manner of their preservation; a quality that improvised pieces, unless adaptations, do not show. The folk preserved them, but did they originate them? Somewhere, as said earlier, behind the theme, story, or melody of the ballad which is to find perpetuation, there must be more than ordinary impetus; widespread interest such as that centering about outlaws like Jesse James or Robin Hood; in battles like those between the Texas Rangers and the Indians, or those of the Scottish Border; in national characters like Garfield, or like the Percy and the Douglas. The pieces that stand out as of better execution or more striking character are those that persist. Improvised origin at some homogeneous folk-gathering would not typically afford the élan to bring outside currency. In the ballads collected by Professor Child, those which are nearest to folk life and to folk style, as paralleled by the western pieces, those which might most plausibly have had the type of origin sketched by Professor Kittredge for "The Hangman's Tree," are those farthest

1 Introduction to English and Scottish Popular Ballads, pp. xxv-xxviii. Professor C. Alphonso Smith, "The Negro and the Ballad," in the University of West Virgini Alumni Bulletin, January, 1913, suggests as an example of modern communal compo 
from the "good" type established by pieces dealing with aristocratic themes.

The ballad last cited, "The Hangman's Tree," is selected as typical to illustrate the probable manner of composition of the English and Scottish ballads, by both Professor Kittredge, ${ }^{1}$ who bases his argument on an Americanized version, and Professor Gummere. $^{2}$ On the other hand, Mr. T. F. Henderson ${ }^{3}$ urges of this piece that it is far from a typical instance in that all ballads are not fashioned on the model of this; nor are they by any means so simple in plot or so inevitable in structure and diction. It may be added here that in point of characters the ballad in question is exceptional also. It is nearly the only piece in the collection in which the main characters, at least in the older versions, do not have perforce to be interpreted as people of rank. The versions that we have of "The Hangman's Tree" are neutral; they do not specify. Possibly then this particular ballad might afford an instance of humble people improvising about themselves, not choosing some theme more germane to the harper and the castle hall than to the cottage and the village throng. Yet it is as likely, or likelier, that the ballad as we have it has descended from one of definitely higher life; much as "Lord Randal" evolved into the "Johnny Randall" of a Colorado railway camp, or "The Two Brothers," Sir John and Sir Willie, of the Scottish ballad, "became merely "Two Little Boys" in their New World home. To find a piece which might plausibly illustrate the unanimous village throng collaborating on a suitable theme, a composition was chosen which instead of being representative was nearly the only one of its kind to be found by canvassing the whole group.

sition certain negro revival hymns and plantation melodies. "If one will attend a negro revival in the country or suburban districts of the South he can see and hear this process of communal composition, about which so much has been written and surmised." The illustrations cited by Professor Smith are simpler than "The Hangman's Tree." They are songs, not poetical narratives, and they deal with the familiar revival material of the negroes. In general nature, in suitability to the composers and to the occasion, they are much what might be foreseen.

1 Introduction to English and Scottish Popular Ballads (1904), p. xxv.

2 The Popular Ballad (1907), p. 101; also the Nation, August 29, 1907; also Democracy and Poetry (1911), p. 193.

3 The Ballad in Literature (1912), pp. 72-79.

- See note 4 supra, p. 198. 
We are told that "the ballad genesis is more plainly proved for the Faroes than for any other modern people." 1 But those originated by the Faroe Islanders, when they improvised ballads, seem to be wholly of the expected character and general style. Witness the narrative cited by Professor Gummere of the Faroe fisherman and his boat, ${ }^{2}$ or the folk tale of the girl carried off by Frisian pirates. ${ }^{3}$ Clearly, like the southwestern cowboys, the Faroe Islanders improvised concerning the events nearest them, and in equally crude style, no doubt. Nor is it proved of these pieces so created that they gained much currency. ${ }^{4}$ The best ballads from the Faroes are derived admittedly from Icelandic literary tradition. They tell not of fishermen or girls carried off by pirates but of the deeds of Sigurd. They are pieces of high descent. Similarly with the songs of more contemporary communal creation in modern Europe brought together with painstaking erudition by Professor Gummere. $^{5}$ The pieces improvised concern the singers themselves, their own lives and daily work. They are songs rather than ballads, nor is there evidence that they ultimately developed into more elaborate form, or attained higher poetical quality; nor that they gained much diffusion. Like the Faroe pieces, they are on a par with the improvised cowboy songs rather than with the English and Scottish popular ballads. The soldiers who took part in the Battle of Otterbourne may have made their own songs of that battle, ${ }^{6}$ but their songs would have had little chance to endure beside those made by the minstrels who are urged to "play up for your warison,"" or those from some yet higher source. Once a good one was made, expressing "the mind and heart of the people," much, say, as did

1 Gummere, The Popular Ballad (1907), p. 69. His position is, specifically, that the popular ballad arises from communal beginnings, such as those found among the Faroe Islanders, followed by an "epic development." When, where, or from whom the latter comes, he cannot, or does not, clearly set forth.

2 Ibid., p. 24.

3 Ibid., pp. 109, 150, etc.

- Accessible in H. Thuren's Folke Sangen paa Farørne (1908). Mr. Henderson remarks of the Faroe fisher ballads that "they are very woeful specimens of verse, of interest only from their touching and almost childish naiveté; and they are not sung to native melodies of ancient flsher tradition or of new fisher improvisation but to lugubrious tunes borrowed, according to Thuren, from Protestant Psalmody." - The Ballad in Literature, p. 88.

5 The Beginnings of Poetry (1901), pp. $202 \mathrm{ff}$.

- Gummere, The Popular Ballad, p. 265, but see also his admission, p. 260, of minstrel part in the ballad as we have it.

${ }^{7}$ Stanza 43 . 
the "Marseillaise," "John Brown's Body," "Marching through Georgia," or "Auld Lang Syne," (does it matter much to those who sing these pieces who originally composed them?), public interest in, and memory of, the event and the song would furnish the necessary impetus for diffusion. From this point of view, if songs of the Faroe fisher folk, or of the toiling village throngs of modern Europe, or of the Texas cowboys, throw light on the manner of origin of the English and Scottish popular ballads, they point to a genesis for the latter of some much higher kind.

Nor, if the parallel of the western pieces be still followed out, is the style of expression of the English and Scottish ballads a style which we should expect to find shepherds or plowmen or weavers, "spinsters and knitters in the sun," evolving from crude collaboration. The older the version, the nearer to the original form, the better is the style likely to be. The latter, like the subject-matter, bears the hall mark of a high descent. In the oldest pieces, as "The Battle of Otterbourne," there are phrases and alliterative formulae recalling that fixed poetic vocabulary not used in ordinary speech (bern, freke, byrd, etc.) which Dr. Bradley reminds us was characteristic of a group of professional poets about the middle of the fourteenth century. ${ }^{1}$ The diction of the older ballads preserves many of the stereotyped alliterative phrases of the metrical romances. To the present writer, another mannerism of ballad expression seems well worthy of attention, in the search for stable testimony as to origins. ${ }^{2}$ The liking for "shifted" or "wrenched" accent (Douglas, Londón, forést) is familiar to all students of traditional English balladry. For explanation of this it would seem clear that we have to proceed from French loan words, preserving for a while their final accent (certáyne, countrée, pité, menyé, chambér), with occasional transfer of this accentuation, through confusion, to native words having properly initial accent ${ }^{3}$ (ladié, daughtér, mornnýge, lesýnge.)

1 The Cambridge History of English Literature, I, chap. xix.

2 Even Professor Gummere is troubled by the thought of an aristocratic origin for the ballad stanza, derived almost certainly, it was long believed, from the classical septenarius (Old English Ballads, xxx, note 3); but the whole subject of the genesis of the ballad stanza is too dark for very safe inference to be drawn therefrom. See Saintsbury, History of English Prosody (1906), for a recent discussion of the origin of the ballad measure.

3 Some prosodists might hold that these "wrenched accents" are only instances of "pitch accent," and derive them from Old English. Others may feel that they are 
The words so stressed were prominent words in the line, were often rhyme words, the most stable words in the stanza; hence the usage established itself as traditional and remained a persistent feature of ballad diction. But the origin of the practice is surely to be found in aristocratic French, not in the vernacular initial accent of the folk. The tradition was more likely to emerge from the rhyme modes of the higher classes, or from a professional singing fraternity, than from humble "spinsters and knitters in the sun." To judge from the character of the stories narrated and the life reflected, perhaps from the general nature of the ballad stanza, and of the expression, the English and Scottish pieces may well have been favored and fostered by the upper classes, as they almost certainly were in Denmark. They might well have been sung in the halls of castles or in the market place with harp accompaniment by accomplished minstrels. ${ }^{1}$

The parallel suggested by the writers quoted at the opening is as interesting as they promised; although conclusions from it, if they are to be made at all, are not to be made hurriedly. It is clear, however, that the better analogy for the Old World pieces is afforded not by those created by the cowboys themselves but by those which have drifted among them and found preservation there. $^{2}$ On the whole, if either of the two leading schools of thought

merely crudenesses, made possible by the fact that the ballads were sung not read. But the final accent is too clearly marked, and is used too definitely and too frequently, at least in the earlier pieces, to be explained as something merely casual or fortuitous.

1 The ministrel of the pre-modern era, that conspicuous figure of the mediaeval world, was a very different figure from the minstrel of the seventeenth and eighteenth centuries, "ruled out of court" by Professor Kittredge. The latter says: "There is no reason whatever for believing that the state of things between 1300 and 1600 was different [as regards minstrel transmission of ballads] from that between 1600 and 1800-and there are many reasons for believing that it was not different" (Introd. to English and Scottish Popular Ballads, p. xxiii). But the change from feudal to modern conditions, and especially the introduction of printing, would be quite enough to bring difference in the standing of minstrelsy and in the character of its song.

For the best account of mediaeval minstrels, the higher and the lower orders, the wide scope of their singing, their fondness for dialogue, and the like, see $\mathrm{E}$. $\mathrm{K}$. Chambers, The Mediaeval Stage, (1903), I, chaps. iii and iv.

${ }^{2}$ It should not much longer be reiterated, at least without careful definition and restriction to a certain type, that the making of popular ballads is a "closed account." Already there has accumulated in outlying regions a considerable body of American ballads, somehow finding diffusion among the people and preserved in many communities by oral tradition. For a general survey of these, see H. M. Belden, "Balladry in America," in the Journal of American Folk-Lore, January-March 1912, and the bibliographical references there. The style of these American pieces is not that of the English and Scottish popular ballads; but that is no more to be expected than that 
regarding the origin of the English and Scottish ballads may be said to find support in the testimony of the latter's New World analogues, it is not that school which defines by origin in folk composition, but that which presupposes a higher descent, and defines by style and by destination. In the case of the New World pieces, we are dealing with genuine "humble poetry of simple folk"; in the case of the English and Scottish popular ballads we are dealing with poetry of aristocratic material, having traces blurred by time of an aristocratic manner. Working from both subject-matter and style, it would seem that among the cowboys of the Southwest are reproduced not the conditions which created the English and Scottish popular ballads but rather, it may be, some of the conditions which preserved them.

\section{UNIVERSITY OF NEBRASKA}

Lourse Pound

modern book poetry should continue the style of mediaeval book poetry. Surely it should not be said much longer that folk-ballads or traditional ballads, "popular" ballads in the usual sense of that term, are no longer living things; that real folk-ballads are practically extinct. The distinction between "popular," "pure," or "genuine" ballads and "vulgar" ballads, the former ballad type the product of the people in a special sense, under social conditions no longer existing in England or America, the only type of ballad to be claimed for folk-lore, and a type now obsolete; the latter or socalled "vulgar" ballad type written for the people, a low form of "literature" in the usual notation of that term, and not belonging to folk-lore-this distinction, so long insisted upon and held to be of such importance, serving for many as basic in ballad classification, is probably not sound; at least not in so far as it is based on origin rather than style. It would seem that there need be no difference between the kinds in origin; that one kind does not belong to folk-lore to the exclusion of the other; also that neither, despite the special pleading of Professor Gummere, need represent or be a direct continuant of primitive poetry. 